\title{
Sensitive and validated HPLC method for determination of paclitaxel in human serum
} G. Rajender and N. G. B. Narayanan.

\section{Research \& Development Division, Relisys Medical Devices Ltd (RMDL), Hyderabad-501 510, Andhra Pradesh.} dr.grajender@gmail.com

Abstract: Determination of paclitaxel in human blood sample by HPLC method using carbamazepine as internal standard is described. The absolute recovery of paclitaxel from human serum was $>90 \%$ and the limit of quantification was $0.05 \mu \mathrm{g} / \mathrm{ml}$. The intra-day relative standard deviation (RSD) ranged from 1.02 to $3.73 \%$ at $1.0 \mu \mathrm{g} / \mathrm{ml}, 1.16$ to $5.03 \%$ at $10.0 \mu \mathrm{g} / \mathrm{ml}$ and 3.33 to $5.01 \%$ at $50.0 \mu \mathrm{g} / \mathrm{ml}$. The inter-day RSD were $1.03,2.16$ and $1.95 \%$ at $1.0,10.0,50.0 \mu \mathrm{g} / \mathrm{ml}$, respectively. The method can be applied to measure the serum concentration of paclitaxel in pharmacokinetic and elution kinetics.

Keywords: Paclitaxel, human blood sample, serum, HPLC.

Introduction

Paclitaxel is a mitotic inhibitor used in cancer chemotherapy originally isolated from the bark of the Pacific yew tree, Taxus brevifolia and named as 'Taxol'. Paclitaxel is found use in treating patients with lung, ovarian, breast cancer (National Cancer Institute facts sheets: http:/www.oncolink.com) head and neck cancer. Paclitaxel is used as an anti-proliferative agent for the prevention of restenosis of coronary stents; locally delivered to the wall of the coronary artery, a paclitaxel coating limits the growth of neointima (scar tissue) within stents (Heldman et al.,2001).

Paclitaxel (Fig.1; Wani et al., 1971) interferes with the normal function of microtubule breakdown. This destroys the cell's ability to use its cytoskeleton in a flexible manner. Specifically, paclitaxel binds to the $\beta$ subunit of tubulin. Tubulin is the "building block" of microtubules, and the binding of paclitaxel locks these building blocks in place. The resulting microtubule/paclitaxel complex does not have the ability to disassemble. This adversely affects cell function because the shortening and lengthening of microtubules is necessary for their function as a mechanism to transport other cellular components. During mitosis, microtubules position the chromosomes during their replication and subsequent separation into the two daughter-cell nuclei (Kumar, 1981).

Taxol is rarely used as monotherapy but it is administered with other anticancer drugs to create a synergy of action allowing Taxol doses to be lowered, consequently the side effects decrease. Taxol has demonstrated synergy with the pyrimidine analogue5flurouracil (5FU) (Patton, 2000) gemcitabine (Rinaldi, 2000), some anticonvulsants (Kuhn, et al., 1997) and flavopirido (Schwartz et al., 1999). When Taxol is given with other drugs, there is a need to evaluate pharmacokinetic parameters using a validated assay, Research article Clndian Society for Education and Environment (iSee)

with high specificity in order that co-administered drugs and/or metabolites do not interfere with the measurement of Taxol. A review of early methods of determination of paclitaxel concentrations has been presented (Sparreboom \& Van Tellingen, 1998).

Various experiments have been performed to improve the bioavailability of this drug such as binding with polymers (Nannan Panday et al., 1998), coadministration with Cyclosporine A (Schellens et al., 1998) or administration by liposome's (Sharma et al., 1994). To be able to compare the effectiveness of different formulations, Taxol concentrations need to be measured with a fully validated method with sufficient sensitivity to measure plasma levels from the "poor" formulation as well as the improved formulation.

Hence simple, sensitive HPLC method with UV detection has been developed for the quantitative determination of paclitaxel in serum samples using protein precipitation and carbamazepine as internal standard. The method offers the advantage of simplicity with adequate sensitivity, selectivity, precision and accuracy. This analytical method can be used in therapeutic monitoring the drug in cancer patients on paclitaxel therapy and also in other pharmacokinetic studies.

\section{Materials and methods}

Paclitaxel was purchased from Dr. Reddy labs, Hyderabad, India. Carbamazepine was kind gift from Hetro drugs, Hyderabad India. Methanol (HPLC grade) and Acetonitrel (HPLC grade) were purchased from Merck. Double distilled water was used in this study. Serum was collected from healthy human volunteers.

\section{Standard solutions}

Stock solutions of $1 \mathrm{mg} / \mathrm{ml}$ of paclitaxel and carbamazepine were prepared in methanol and stored at $4^{0} \mathrm{C}$. Appropriate dilutions of paclitaxel were made in Acetinitrile to produce working stock solutions of 100,10 , $1 \mu \mathrm{g} / \mathrm{ml}$. these dilutions were used to spike serum in the preparation of calibration curves. Internal standard was used directly from the stock solution...Calibration samples were prepared by spiking $200 \mu \mathrm{L}$ of blank serum with the appropriate amount of the drug on the day of analysis. Samples for the determination of recovery, precision and accuracy were prepared by spiking control serum in appropriate concentrations $(1,10,50 \mu \mathrm{g} / \mathrm{ml})$ and stored at $-20^{\circ} \mathrm{C}$.

\section{Extraction procedure}

To $200 \mu \mathrm{L}$ of serum sample, equal volume of different concentration of paclitaxel and methanolic solution of

"Paclitaxel"

http://www.indjst.org
Rajender \& Narayanan Indian J.Sci.Technol. 
carbamazepine $(5 \mu \mathrm{g})$ as internal standard (I.S) were added and mixed. $200 \mu \mathrm{l}$ of acetonitrile was added and the contents were vortexed for $1 \mathrm{~min}$ using a cyclomixer (Remi Instruments, Mumbai, India) and centrifuged at $13000 \mathrm{rpm}$ for $8 \mathrm{~min}$. at $37^{\circ} \mathrm{C}$ in Biofuge fresco centrifuge (Hereaus, Germany). $20 \mu \mathrm{l}$ of the supernatant was injected onto HPLC. Calibration standards were prepared in the range of 1.0 to $250 \mu \mathrm{g} / \mathrm{ml}$.

\section{Chromatographic conditions}

The HPLC system (Shimadzu, Kyoto, Japan) consisted of LC-8A solvent delivery module and SPD10AVP UV-Visible spectrophotometric detector and phenomenax C-18 column (250x4.60 mm-5microns) was used for the analysis. Sensitivity was set at 0.001 a.u.f.s. Mobile phase consisting of water, acetonitrile and methanol (40:30:30: v/v) was used at a flow rate of $1.0 \mathrm{ml} / \mathrm{min}$. The elute was monitored using a UV/VIS detector set at $228 \mathrm{~nm}$.

Results

\section{Chromatography}

Typical chromatogram corresponding to blank serum and serum sample obtained after adding $200 \mu$ of 100 $\mu \mathrm{g} / \mathrm{ml}$ paclitaxel are shown in Fig. 2 and 3, respectively. No endogenous interfering peaks were visible in blank serum at retention time of paclitaxel and the I.S there by confirming the specificity of the analytical method. Both analyte and the I.S were separated with retention time of 6.1 and $8.3 \mathrm{~min}$, respectively. System suitability parameters for the method were as follows: Theoretical plates for paclitaxel and I.S were 2024 and 2348. Tailing factors were less than 1.25 and 1.23 for paclitaxel and I.S respectively. Resolution between drugs and I.S was 3.12.

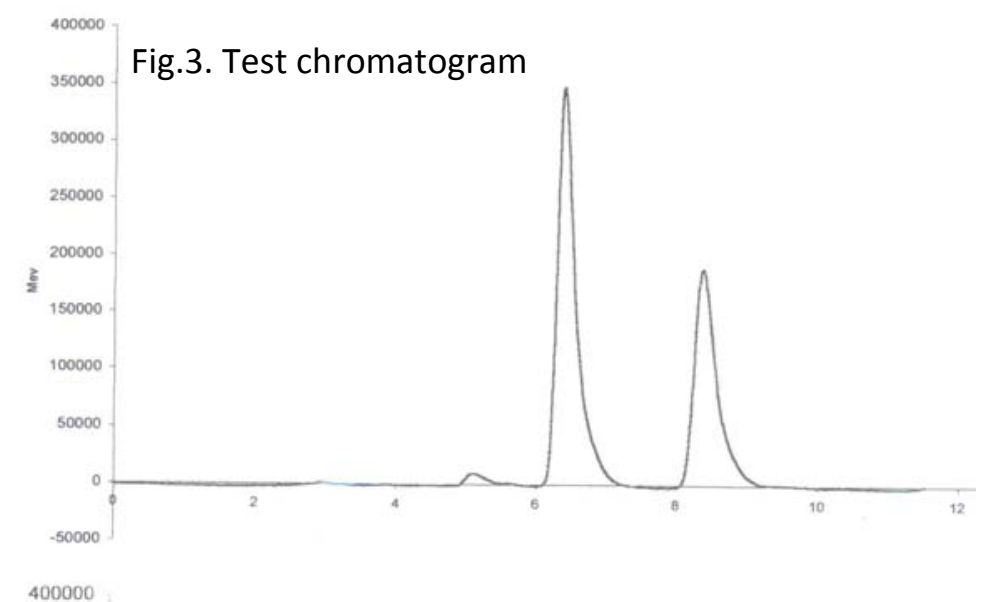

Fig.2. Blank chromatogram

\section{0}

250000

200000

150000

100000

50000

0
-50000

Research article

CIndian Society for Education and Environment (iSee)
"Paclitaxel" http://www.indjst.org

\section{Quantification}

Peak area ratios of paclitaxel to the I.S were measured. A representative calibration graph of peak area ratio (paclitaxel to I.s) versus concentration in the range of $1 \mu \mathrm{g}$ to $250 \mu \mathrm{g}$ resulted in regression equation $Y=69716 x+48983 \quad\left(r^{2}=0.999\right) \quad(F i g .4)$. The lowest concentration with relative standard deviation (RSD) $<20 \%$ was taken as lower limit of quantification (LLOQ) and was found to be $0.05 \mu \mathrm{g} / \mathrm{ml}$. The RSD and S/N ratio at LLOQ were found to be $15 \%$ and $6 \%$ respctively.

\section{Precision}

Precision of assay was determined by analyzing serum samples containing paclitaxel at three different concentrations. Samples for precision study were obtained by spiking blank serum with the analyte solution at each concentration in bulk and the aliquots were stored in ependroff tubes at $-4^{0} \mathrm{C}$. The intra-day precision was determined by analyzing six spiked serum samples at each concentration on the same day. For the determination of inter-day precision, fortified samples were analyzed on four different days. The intra-day relative standard deviation (RSD) ranged from 1.02 to 3.73 at $1.0 \mu \mathrm{g} / \mathrm{ml}, 1.16$ to 5.03 at $10.0 \mu \mathrm{g} / \mathrm{ml}$ and 3.33 to $5.01 \mu \mathrm{g} / \mathrm{ml}$. The inter day RSD were $1.03,2.16$ and 1.95 for 1,10 , and $50 \mu \mathrm{g} / \mathrm{ml}$ respectively (Table 1). These values are within the limits $(<15 \%)$ specified for inter and intra day precision $(9,10)$.

Recovery and accuracy

The extraction recovery of paclitaxel was estimated at $1,10,50 \mu \mathrm{g} / \mathrm{mL}$ concentrations. Serum samples (in six replicates) containing paclitaxel and I.S were extracted and analyzed. Six samples containing similar concentrations of the compound in mobile phase were directly injected and peak areas were measured. Absolute recovery was calculated by comparing the peak areas for direct injection of pure paclitaxel in Acetonitrile with those obtained by serum samples containing same amount of paclitaxel. The absolute recoveries ranged from 92.49 to 99.12 (Table 2). The accuracy of method was verified by comparing the concentrations measured for paclitaxel spiked in serum with the actual added concentrations. The results indicate that the accuracy of the method was 97.01 to $99.67 \%$.

Discussion

The present method for determination of paclitaxel in serum samples is specific, accurate and precise. The calibration curve was linear and the method was suitable for analysis of serum samples in the concentration range of $0.5 \mu \mathrm{g}$ to $500 \mu \mathrm{g} / \mathrm{mL}$. This method was used for analysis of serum samples collected during a pharmacokinetic study. HPLC chromatogram of serum sample with out I.S showed no peaks at retention time the I.S indicating that there was no interference from serum endogenous pecks. In conclusion, the HPLC method presented here is suitable for

Rajender \& Narayanan Indian J.Sci.Technol. 
analysis of paclitaxel serum during protein binding, tissue distribution and elution kinetics.

Table 1. Intra and inter day variation of paclitaxel in human serum

\begin{tabular}{|c|c|c|c|c|}
\hline \multicolumn{2}{|c|}{$\begin{array}{l}\text { Spiked } \\
\text { concentration day }\end{array}$} & \multirow[t]{2}{*}{ Mean $(\mu \mathrm{g} / \mathrm{ml})$} & \multicolumn{2}{|c|}{$\begin{array}{c}\text { Measured } \\
\text { concentration* }\end{array}$} \\
\hline \multicolumn{4}{|l|}{$\begin{array}{l}\text { Intra-day } \\
\text { variation }\end{array}$} & \\
\hline \multirow[t]{5}{*}{$1.0 \mathrm{ug} / \mathrm{ml}$} & 0 & 0.98 & 0.01 & 1.02 \\
\hline & 1 & 1.02 & 0.02 & 2.05 \\
\hline & 2 & 1.35 & 0.05 & 3.70 \\
\hline & 3 & 0.96 & 0.01 & 1.51 \\
\hline & 4 & 0.99 & 0.03 & 3.73 \\
\hline \multirow[t]{5}{*}{$10.0 \mathrm{ug} / \mathrm{ml}$} & 0 & 10.23 & 0.32 & 3.12 \\
\hline & 1 & 9.87 & 0.49 & 4.96 \\
\hline & 2 & 10.53 & 0.53 & 5.03 \\
\hline & 3 & 10.27 & 0.12 & 1.16 \\
\hline & 4 & 9.06 & 0.27 & 2.98 \\
\hline \multirow{5}{*}{$50.0 \mathrm{ug} / \mathrm{ml}$} & 0 & 50.13 & 1.67 & 3.33 \\
\hline & 1 & 50.95 & 2.03 & 3.98 \\
\hline & 2 & 50.01 & 2.51 & 5.01 \\
\hline & 3 & 49.27 & 1.98 & 4.01 \\
\hline & 4 & 48.97 & 1.67 & 3.41 \\
\hline \multicolumn{5}{|l|}{$\begin{array}{l}\text { Inter-day } \\
\text { variation }\end{array}$} \\
\hline $1.0 \mu \mathrm{g} / \mathrm{ml}$ & & 0.97 & 0.01 & 1.03 \\
\hline 10. $\mu \mathrm{g} / \mathrm{ml}$ & & 10.62 & 0.23 & 2.16 \\
\hline $50.0 \mu \mathrm{g} / \mathrm{ml}$ & & 49.63 & 0.97 & 1.95 \\
\hline
\end{tabular}

Table: 2. Recovery and accuracy of determination of paclitaxel in human serum

\begin{tabular}{|l|l|l|l|}
\hline $\begin{array}{l}\text { Concentration } \\
(\mu \mathrm{g} / \mathrm{ml})\end{array}$ & $\begin{array}{l}\text { Absolute recovery } \\
(\mathrm{mean} \pm S . D . n=6)\end{array}$ & $\begin{array}{l}\text { Accuracy }(\%) \\
(\text { mean } \pm S . D . n \\
=6)\end{array}$ & $\begin{array}{l}\text { Range } \\
(\mu \mathrm{g} / \mathrm{ml})\end{array}$ \\
\hline 1.0 & $92.49 \pm 1.34$ & $99.67 \pm 1.97$ & $0.92-1.23$ \\
\hline 10.0 & $98.97 \pm 1.07$ & $98.32 \pm 1.32$ & $9.78-10.32$ \\
\hline 50.0 & $99.12 \pm 2.31$ & $97.01 \pm 0.99$ & $48.98-51.23$ \\
\hline
\end{tabular}

Fig.No.4 Calibration curve of Paclitaxel

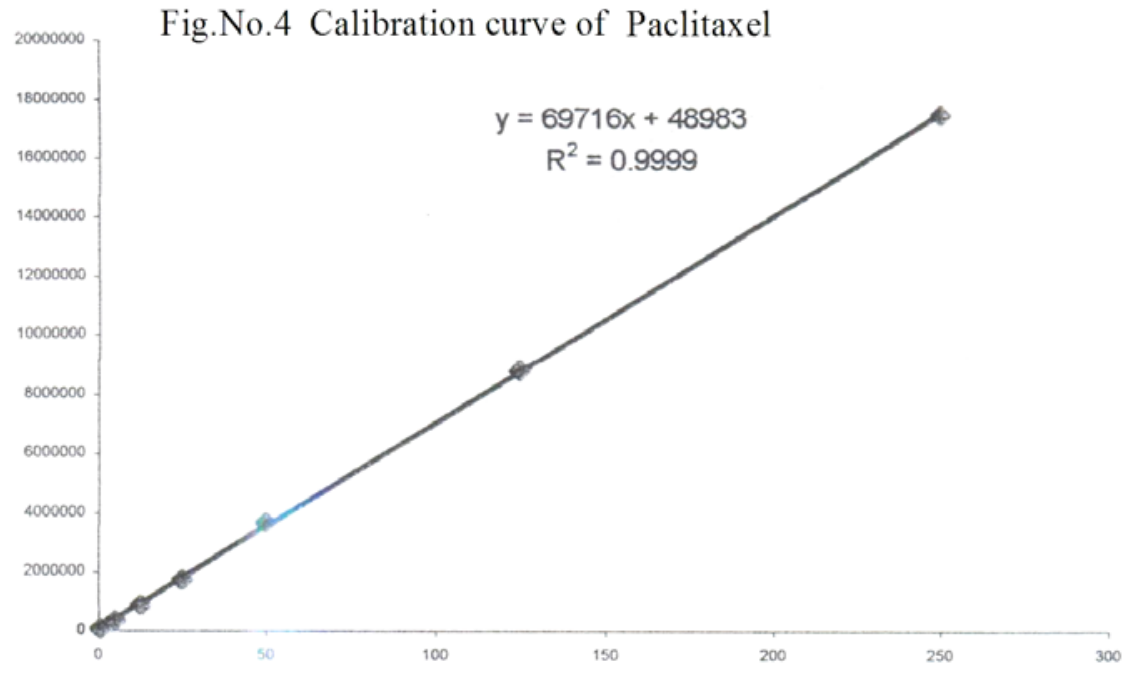

Vol.2 No 5 (May 2009)

ISSN: 0974- 6846
Hunter W, and Froehlich J (2001) Paclitaxel stent coating inhibits neointimal hyperplasia at 4 weeks in a porcine model of coronary restenosis. Circulation. 103, 2289-95.

2. Kuhn J, Rizzo J, Chang S, Schold C,Spence A, Berger M, Robbins $\mathrm{H}$, Metha M, Bozik M, Fulton D, Rector D and Prodos M (1997) Effect of anticinvulsants (ACs) on the phromacokinetics (PK) and metabolic profile of Paclitaxel. Am. Soc. Clin. Oncol. 16, 224a.

3. Kumar N (1981) Taxol-induced Polymerization of Purified Tubulin. J. Biological. Chem. 256, 1043510441.

4. Nannan Panday VR, Meerum Terwot JM and Ten Bokkel Huinink WW (1998) The role of pro drug therapy in the treatment of cancer. Proc. Am. Soc. Clin. Oncol. 17,742a.

5. Patton JF, Suzanne J, Fanthony G, Haimworth J, Willent N, Baker, Bechert J, Lacerna L and Howard Buris (2000) Weekly paclitaxel prolongated oral eniluracil/ 5-flurouracil: results of a phase-। combination study. Proc. Am. Soc. Clin. Oncol. 19, 746a.

6. Rinaldi, DA, Lormand N, Brierre J, Cole J, Stagg P, Fontenot F, Buller E and Rainer J (2000) A phase 1 trial of gemcitabine (GEM) and paclitaxel (PAC) in patients with advanced solid tumors, administered every 21 days (LOA-2). Proc. Am. Soc. Clin. Oncol. 19, 848a.

7. Schellens JHM, Meeru JM, Bokke HWW, Rosing $\mathrm{H}$, Tellingen $\mathrm{O}$, Swart $\mathrm{M}$, Duchin $\mathrm{KL}$ and Beijner JH (1998) Cyclosporin A (CsA) strongly enhances oral bioavailability of paclitaxel (Pac) in cancer patients. Pro. Am. Soc. Clin. Oncol. 17, 717a.

8. Schwartz GK, Kaubish A, Saltz $L$ and Lison D (2000) Phase 1 trial of sequential paclitaxel and the cyclin dependent kinase inhibitor flavopiridol. Proc. Am. Soc. Clin. Oncol. 18, 160a.

9. Sharma A, Conway WD and Staudinger RM (1994) Reverse-phase highperformance liquid chromatographic determination of taxol in mouse plasma. J. Chromatogr. 655, 315-319.

10. Sparreboom $A$ and Van Tellingen $O$ (1998) Preclinical pharmacokinetics of paclitaxel and docetaxel. Anti Cancer Drugs. 8, 1-17.

11. Wani $M$, Taylor $H$, Wall $M$, Coggon $P$ and McPhail A (1971) Plant antitumor agents. VI. The isolation and structure of taxol, a novel antileukemic and antitumor agent from Taxus brevifolia. J.Am. Chem. Soc. $93,2325-2327$.

\section{References}

1. Heldman $A$ Cheng $L$, Jenkins $G$, Heller $P$, Kim $D$, Ware M, Nater C, Hruban R, Rezai B, Abella B, Bunge K, Kinsella J, Sollott S, Lakatta E, Brinker J,
Rajender \& Narayanan Indian J.Sci.Technol. 